\title{
Coincidence of Nemaline Myopathy and Agenesis of Corpus Callosum in a Newborn Infant: Case Report
}

\author{
Yenidoğanda Nemalin Miyopatisi ve Korpus \\ Kallosum Agenezisi Birlikteliği: Olgu Sunumu
}

Sinem Akbay (1)

Esra Ozer $\mathbb{0}$

Ozkan Ilhan (1)

Berat Kanar (1)

Seyma Memur $\mathbb{0}$

Gulden Diniz (D

Dilek Cavusoglu (1)

Nihal Olgaç Dündar đo

\begin{abstract}
The diagnosis of the hypotonia during neonatal period is difficult. In the neonatal period, acute illnesses and systemic diseases such as sepsis, congestive heart failure and inborn errors of metabolism should be considered in the differential diagnosis of the patients. Congenital disorders that affect nervous system can be the reason of hypotonia. Nemaline myopathy (NM) is a rare congenital myopathy, characterized with slowly progressive or nonprogressive muscle weakness and the inclusions known as nemaline rods characterized by rod-shaped structures (nemaline bodies) in muscle biopsy specimens. The disease can be presented with hypotonia, feeding problems, repeated respiratory infections, and arthrogryposis. Also, agenesis of corpus callosum (ACC) can result in an interhemispheric disconnection, neurologic problems such as mental retardation, and seizures. Unfortunately, there is no curative treatment for both of them. Herein, we report an infant who was admitted with generalized muscle weakness at the neonatal period and diagnosed as ACC with NM.
\end{abstract}

Keywords: Agenesis corpus callosum, hypotonia, nemaline myopathy, newborn

öz

Yenidoğan döneminde hipotonisitenin tanısı zordur. Yenidoğan döneminde, akut hastalıklar ve sepsis, konjestif kalp yetmezliği ve konjenital metabolik hastalıklar gibi sistemik hastalıklar ayırııı tanıda düşünülmelidir. Sinir sistemini etkileyen konjenital bozukluklar hipotonisitenin nedeni olabilir. Nemalin miyopatisi (NM), yavaş ilerleyen veya progresif olmayan kas zayıflığı ve kas biyopsisinde çubuk şeklindeki yapılar (nemalin cisimleri) ile karakterize olan, hipotoni, beslenme sorunları, tekrarlayan solunum yolu enfeksiyonları ve artrogripozis ile karşımıza çıkabilen nadir bir konjenital miyopatidir. Ayrıca korpus kallozum agenezisi (ACC), hemisferler arasında bağlantısızlık yaratabilmekte, mental retardasyon, konvülziyon gibi nörolojik sorunlarla ortaya çıkabilmektedir. Ne yazık ki ikisi için de iyileştirici bir tedavi yoktur. Burada, yenidoğan döneminde yaygın kas güçsüzlüğüyle başvuran ve nemalin miyopatisi ile korpus kallozum agenezisi tanısı alan bir bebeği sunduk.

Anahtar kelimeler: Korpus kallosum agenezisi, hipotonisite, nemalin miyopatisi, yenidoğan
Alındığı tarih: 07.05.2019

Kabul tarihi: 23.08.2019

Online Yayın tarihi: 06.12.2019

Sinem Akbay

Tokat Devlet Hastanesi,

Neonatoloji,

Tokat - Türkiye

sinemakbay@gmail.com ORCiD: 0000-0003-1266-320X

E. Ozer 0000-0001-7791-1660

Celal Bayar Üniversitesi

Tıp Fakültesi, Neonatoloji,

Manisa, Türkiye

O. Ilhan 0000-0002-6124-9796 Muğla Sıtkı Koçman Üniversitesi

Tıp Fakültesi, Neonatoloji, Muğla, Türkiye

B. Kanar 0000-0001-7886-8932 Mardin Devlet Hastanesi, Neonatoloji, Mardin, Türkiye

S. Memur 0000-0001-6099-7496 Kanuni Sultan Süleyman Eğitim ve Araştırma Hastanesi, Neonatoloji,

istanbul, Türkiye

G. Diniz 0000-0003-1512-7584 izmir Tepecik Eğitim ve Araştırma Hastanesi, Patoloji, Izmir, Türkiye

D. Cavusoglu 0000-0003-4924-5300 Afyon Kocatepe Üniversitesi, Pediatrik Nöroloji, Afyon, Türkiye

N. Olgaç Dündar 0000-0002-5902-3501 Izmir Katip Çelebi Üniversitesi, Pediatrik Nöroloji, Izmir, Türkiye 


\section{INTRODUCTION}

Nemaline myopathy (NM) is a rare congenital myopathy defined by the presence of inclusions known as nemaline rods in muscle fibers and characterized with weakness, hypotonia, and depressed deep tendon reflexes. Muscle weakness is usually most severe in the face, neck, and the proximal limb muscles. Until now, six forms of the disease are known and classified by onset and severity of motor and respiratory involvement. It has an autosomal dominant or recessive inheritance pattern ${ }^{(1)}$. There is no curative treatment. The cause of death is usually due to respiratory failure (2). Here, to our knowledge we present a newborn with $\mathrm{NM}$ and $\mathrm{ACC}$ as the first report on coincidence of ACC and NM in the literature.

\section{CASE REPORT}

A male infant with a 34-week gestational age, and a birth weight of 2100 grams, was born to a 22-yearold woman by normal spontaneous vaginal delivery. His 1 , and 5. minute-Apgar scores were 6 , and 8 points, respectively. He was referred to neonatal intensive care unit after delivery due to hypotonicity. His prenatal history was unremarkable. The parents were first cousins and his five-year old brother was healthy. There was no family history of neuromuscular disease.

On admission, he was hypotonic and had a little spontaneous activity. There was bilateral chorioretinal atrophy. Serum creatinine kinase levels and the cerebrospinal fluid analyzes were normal. Cranial magnetic resonance imaging revealed the presence of a corpus callosum agenesis. Results of metabolic screening tests and the electroneuromyography (EMG) were within normal limits. Muscle biopsy was performed at the age of 142 days. Microscopic examination revealed the presence of red-black-colored, short rod-like structures which were condensed predominantly on small-sized myofibrils and compatible with nemaline myopathy. The patient was fed via orogastric tube because of swallowing problems. He died at the age of 10 months due to severe respiratory tract infection.

\section{DISCUSSION}

Evaluation of neonatal hypotonia is sometimes very difficult. In the neonatal period, differential diagnosis must include acute illnesses and systemic diseases such as sepsis, congestive heart failure and inborn errors of metabolism. There are two large groups: the supraspinal conditions that can be called central hypotonia and the segmental conditions, which are more appropriately called motor unit hypotonia (originating from anterior horn cell with muscular involvement) ${ }^{(3)}$.

Nemaline myopathy, is a rare form of congenital myopathy characterized by slowly progressive or nonprogressive muscle weakness and the presence of inclusions known as nemaline rods (Greek nema:thread) in skeletal muscle fibers ${ }^{(4)}$. By now, six forms of the disease are known and classified by onset and severity of the symptoms ${ }^{(1,2)}$. It can be presented with hypotonia, feeding problems, repeated respiratory infections, arthrogryposis multiplex congenita as in our case and muscle weakness which is usually most severe in the face, the neck flexors and the proximal limb muscles ${ }^{(1,2,4)}$. During the prenatal period, there can be some abnormalities including polyhydramnios, decreased fetal movements, abnormal presentation, preterm labor or fetal distress can be seen in neonatal onset of NM ${ }^{(2)}$.

Corpus callosum transmits information between cerebral hemispheres. Alterations characterized by partial genesis or agenesis of the corpus callosum can generate an interhemispheric disconnection ${ }^{(5,6)}$. Common abnormalities in acallosal patients are mental retardation, seizures, ocular anomalies, gyral abnormalities, and hydrocephalus (7). Infectious agents, hypoxia, and chromosomal and genetic factors have all been considered among the etiologies of ACC ${ }^{(5)}$.

The coincidence of NM and ACC is rare. Although overlapping of neurological signs such as hypotonia, difficulty on feeding and developmental delay can be seen in both diseases, there are cardinal differences in their presentation, symptoms and physical examination findings. Muscle weakness is usually at the forefront in NM while ACC frequently presents with 
delays in motor milestones and seizures. Muscle enzymes are usually normal in both conditions, but may be slightly elevated in NM ${ }^{(1)}$. ACC can be prenatally or postnatally diagnosed by using cranial ultrasonography or magnetic resonance imaging ${ }^{(5)}$. The EMG examination typically shows diverse features in NM patients monitored throughout the course of the disease. EMG usually shows normal or mild abnormalities at infancy ${ }^{(1,8)}$.

Our patient was hospitalized due to hypotonia. Firstly, we excluded other diseases which can be presented with weakness. Corpus callosum agenesis was reported on MRI, but it could not explain the medical condition of our patient. So, we applied EMG to clarify the hypotonia. However, it did not help us to make definite diagnosis. Muscular biopsy is required for the definitive diagnosis of specific congenital myopathies ${ }^{(9)}$. Therefore, muscle biopsy was performed. The microscopic evaluation of muscle biopsy specimen of our patient revealed NM. Histopathological examination revealed red-blackcolored, short rod-like structures which were condensed predominantly on small-sized myofibrils which was compatible with nemaline myopathy. The diagnosis of NM is based on the observation of characteristic rod-shaped structures (nemaline bodies) on muscle biopsy stained with Gomori trichrome dye (1).

NM is a clinically and genetically heterogeneous disorder ${ }^{(10)}$. Pathogenic variants in ten different genes have been identified, six of them encode protein components of the muscle thin filament, while three are involved in the protein turnover in the muscle sarcomere (1). We also performed genetic analysis to support the diagnosis. But, no clinically relevant mutation was detected in the results of WES data.

Unfortunately, there is no spesific treatment of NM. Dietary tyrosine supplementation may improve bulbar function, activity levels, and exercise tolerance in NM ${ }^{(11)}$. Daily physiotherapy was performed for our patient, but muscle atrophy and contractures developed. Most of the children with NM die due to respiratory insufficiency or aspiration pneumonia. Morbidity from respiratory tract infections and fee- ding difficulties can be seen ${ }^{(2)}$. Our case was fed with orogastric tube and also had recurrent infections that was the cause of his death.

In the literature, motor and sensory neuropathy with ACC was detected by Dupre et al. in $2003{ }^{(12)}$, Also, accompaniment of global cerebral atrophy, patchy white matter signal abnormalities, delayed myelination, pachygyria and diffuse leukomalacia to NM was reported by Ryan et al. (2). But there is no case report related to coexistence of ACC with NM. Besides, bilateral chorioretinal atrophy was found during eye examination and this finding has not been reported in ACC or NM so far.

In conclusion; differential diagnosis of hypotonia in neonatal period is difficult. When hypotonia cannot be explained by the presence of agenesis of the corpus callosum, accompanying of muscle disorders such as nemaline myopathy should be remembered and muscle biopsy should be kept in mind even though serum creatinine and EMG are within normal limits.

Conflict of Interest: None.

Informed Consent: Obtained from the patient's relatives.

Çıkar Çatışması: Yoktur.

Hasta Onamı: Hasta yakınından onam alındı.

\section{REFERENCES}

1. North KN, Ryan MM. Nemaline Myopathy. In: Adam MP, Ardinger HH, Pagon RA, Wallace SE, Bean LJH, et al. editors. GeneReviews [Internet]. Seattle (WA): University of Washington, Seattle; 1993-2017.

2. Ryan MM, Schnell C, Strickland CD, Shield LK, Morgan G, et al. Nemaline myopathy: a clinical study of 143 cases. Ann Neurol. 2001;50(3):312-20. https://doi.org/10.1002/ana.1080

3. John B, Bodensteiner JB. The evaluation of the hypotonic infant. Semin Pediatr Neurol. 2008;15(1):10-20. https://doi.org/10.1016/j.spen.2008.01.003

4. Sharma MC, Gulati S, Atri S, Seth R, Kalra V, et al. Nemaline rod myopathy: a rare form of myopathy. Neurol India. 2007;55(1):70-4. https://doi.org/10.4103/0028-3886.30433

5. Schulte T, Müller-Oehring EM. Contribution of callosal connections to the interhemispheric integration of visuomotor and cognitive processes. Neuropsychol Rev. 2010;20:17490.

https://doi.org/10.1007/s11065-010-9130-1 
6. Banich MT, Shenker J. Investigations of interhemispheric processing: methodological considerations. Neuropsychology. 1994;8:263-77.

https://doi.org/10.1037/0894-4105.8.2.263

7. Jeret JS, Serur D, Wisniewski K, Lubin RA. Clinicopathological findings associated with agenesis of the corpus callosum. Brain Dev. 1987;9:255-64.

https://doi.org/10.1016/S0387-7604(87)80042-6

8. Youssef NC, Scola RH, Lorenzoni PJ, Werneck LC. Nemaline myopathy: clinical, histochemical and immunohistochemical features. Arq Neuropsiquiatr. 2009;67(3B):886-91. https://doi.org/10.1590/S0004-282X2009000500020

9. Floriach-Robert M, Cabello A, Simón De Las Heras R, Mateos Beato F. Neonatal hypotonia of muscular origin: analysis of
50 cases. Neurologia. 2001;16(6):245-53.

10. Gatayama R, Ueno K, Nakamura H, Yanagi S, Ueda H, et al. Nemaline myopathy with dilated cardiomyopathy in childhood. Pediatrics. 2013;131(6):e1986-90.

https://doi.org/10.1542/peds.2012-1139

11. Ryan MM, Sy C, Rudge S, Ellaway C, Ketteridge D, et al. Dietary L-tyrosine supplementation in nemaline myopathy. J Child Neurol. 2008;23(6):609-13. https://doi.org/10.1177/0883073807309794

12. Dupré N, Howard HC, Mathieu J, Karpati G, Vanasse M, et al. Hereditary motor and sensory neuropathy with agenesis of the corpus callosum. Ann Neurol. 2003;54(1):9-18. https://doi.org/10.1002/ana.77777 